\title{
Assessment of Impacts of Road Infrastructure Using GIS and Remote Sensing: A Case Study of Yatta Sub County
}

\author{
Peter Muthama ${ }^{1}$, Kenneth Mubea ${ }^{2}$ Charles N. Mundia ${ }^{3}$ \\ Institute of Geomatics, GIS and Remote Sensing, Dedan Kimathi University of Technology P.O. Box 657-10100, Nyeri, Kenya
}

\begin{abstract}
Roads play an important role in infrastructure and services in rural development. This is well established in the development literature. There is a direct link which exists between productive investments and growth, social and economic infrastructure (such as roads, electricity, water and sanitation, and communications) facilitates and integrates economic activities. The purpose of this study was to assess the impact of road infrastructure in Yatta Sub County. Descriptive research design was used for the study. GIS and remote sensing were used to capture images on road infrastructure while questionnaires were used to collect data from farmers and business owners. Simple random sampling technique was used to sample respondents for the study. A total of 50 respondents were sampled for the study where all responded giving $100 \%$ response rate. Descriptive statistics such as frequencies ad percentages were used to analyze the quantitative data collected through questionnaires. Qualitative data collected through open ended questions were analyzed thematically. Pre-processing of images involved: layer staking, radiometric correction, pan-sharpening, atmospheric correction and sub setting while post-processing of images involved: Image classification, creating training sites, generating statistical tables, accurate assessment and ground survey using GPS for ground truthing. The study found that roads which cover the Sub County are not sufficient to serve the people of Yatta Sub County effectively. Most of the in-roads in this sub County are in very poor conditions whereby people need to use motor cycle to reach their destinations. The findings revealed that most of the vehicles avoid using earth surface roads as they spent more money on maintaining the vehicles. Where roads are in good conditions, growth of towns such as Matuu, Kithimani and Katangi has greatly been realized. The poor road conditions led to high costs of living and doing business with more time spent on movement from one place to another and difficulty in accessing social facilities. The study recommended that the roads in Yatta Sub-County should be upgraded to facilitate movement of people and goods and that the County Government of Machakos should embrace use of GIS in decision making and planning.
\end{abstract}

Keywords: Road infrastructure, GIS and remote sensing, image processing

\section{Introduction}

The provision of good quality infrastructure is often cited as the most important factor of local and regional development, through which adequate conditions for the growth of new business and attraction of firms to less developed areas are provided. At the same time, the impact of infrastructure development on local and regional development is the subject of various discussions. Despite political influences, the economic impact of infrastructure development is one of the most important considerations in infrastructure policy making. The contribution of infrastructure to the economy has received attention from both policymakers and researchers.

In that context, the removal of obstacles to the movement of goods and factors would itself cause convergence of factor returns and living standards. Underdeveloped infrastructure can be considered as important obstacle to the regional development, and its improvements should spur the economic growth in the region. This notion is well recognized in the relevant theoretical literature. Richardson and Jensen indicate that spatial differences in the European Union (EU) cannot be reduced without a fundamental improvement of transport infrastructure and services to and within the regions where lack of access to transport and communications infrastructure restricts economic development [1].

Transport infrastructures are a vital social and economic resource, and provide access to today's economic and social opportunities (Richardson and Jensen, 2005). Investment in the construction and maintenance of transport infrastructures is vast, and its repercussions can be seen throughout all areas of society [2], [3]. This is why correct planning of transport systems is essential [2]

The increased use of transport systems has gone hand-inhand with a growing awareness of their impacts [4], creating a need for sustainable and integrated development [5] [6]. To attain sustainability in the area of transport it is necessary to have an overall view of the decision-making process; in other words, which involves - transport planning, land use and the environment - must be considered in conjunction rather than viewed in isolation. The great challenge is to succeed in integrating these principles into decisions on transport and land use. This challenge requires tools that can identify and assess the environmental, social and economic aspects of their decisions [7], [8]. A further requirement is to be able to identify which criteria need to be assessed the importance of each one and how they can be integrated; this is a highly challenging task [8].

Although the impact of infrastructure investment on regional economic development is generally assumed to be positive, there is no clear consensus on the magnitude or scope of this effect. A summary of recent literature by Romp and De Haan has concluded that not all studies confirm that public capital has a growth enhancing effect, there is now greater consensus than in the past that public capital promotes economic growth [9]. However, the impact reported by recent studies is not as big as some earlier studies suggested. 


\section{International Journal of Science and Research (IJSR) \\ ISSN (Online): 2319-7064 \\ Index Copernicus Value (2013): 6.14 | Impact Factor (2014): 5.611}

Sustainable rural development is a function of a number of factors in which transportation is of importance. Efficient and effective rural transportation serves as one of the channels for the collection and exchange of goods and services, movement of people, dissemination of information and the promotion of rural economy. Along this line, Owen stated that "Immobility perpetrates poverty", effective transportation eases accessibility to inherent potentials of rural areas which could be harnessed for the development of its economy [10].

In other words, rural transportation provision forms an intrinsic part of rural development strategies, serving as a mechanism and catalyst for rural transformation through the reinforcement of rural development and contributes to poverty reduction by enhancing both equity and efficiency outcomes. In Kenya road infrastructure is generally accepted as a key to economy and it is vital for economic growth and poverty reduction since it plays a key role in enhancing competitiveness. Road infrastructure opens up unconnected regions to trade and investment and improves access to goods, services and employment opportunities. It is upon this background that this study seeks to assess the impact of road infrastructure layout on livelihoods in Yatta Sub County, Machakos County.

\subsection{Problem Statement}

Poor condition roads have made the life very expensive. Good roads facilitate the movement of farmers output between places offering different income earning opportunities; create markets; and serve as an important vehicle for the transfer of information in the absence of telecommunication that facilities. Investments in rural infrastructure and rural services are often not under control of rural households, and are typically provided by the government as public services. Nonetheless, the quality and quantity of social and economic infrastructure and rural services make a big difference to the viability of rural livelihoods.
The roads condition in Yatta Sub County has been poor as evidenced by the drowning of the late Yatta MP Mr. James Mutiso in Mbakoni River (The daily Nation, 2 May 2003, Reporter Mburu Mwangi) which lacked a bridge. This study was therefore aimed at assessing the impact of road infrastructure layout on livelihoods in Yatta Sub County.

\section{Material and Methods}

\subsection{Study Area}

The study area is Yatta Sub County, Machakos County. Yatta Sub County has a total Population of 147,579 as per 2009 Population Census. The Sub County covers an area of $10957.3 \mathrm{~km} 2$. It has three divisions namely: Katangi, Ikombe and Yatta with a total of twenty three sub/Locations (23) and a total of four hundred and twenty four villages (424) as per 2009 population Census. The Sub County is located between 37.343 (W) and 037.807 (E) longitude and latitude between S 0.994 and S 1.5

\section{Data Sources}

The table 1 shows the identified datasets and their sources from different Government Department, Non-Governmental Organizations and Developed Countries.

Table 1: Datasets and Sources

\begin{tabular}{|c|c|}
\hline Type of data & Source of data \\
\hline Base Map & Google Earth \\
\hline Base Map and Topo sheets & $\begin{array}{c}\text { Ministry Of Land, Housing and } \\
\text { Urban Development }\end{array}$ \\
\hline Roads & Ministry of Transport \\
\hline Health Facilities & Ministry of Health \\
\hline $\begin{array}{c}\text { Sub Location maps With } \\
\text { Enumeration Areas }\end{array}$ & KNBS \\
\hline Population Data & KNBS \\
\hline Schools & Ministry of Education \\
\hline Points & Ground Survey \\
\hline Questionnaire & Research assistants \\
\hline Land Use Land Cover & Landsat Images \\
\hline
\end{tabular}




\section{International Journal of Science and Research (IJSR) \\ ISSN (Online): 2319-7064}

Index Copernicus Value (2013): 6.14 | Impact Factor (2014): 5.611

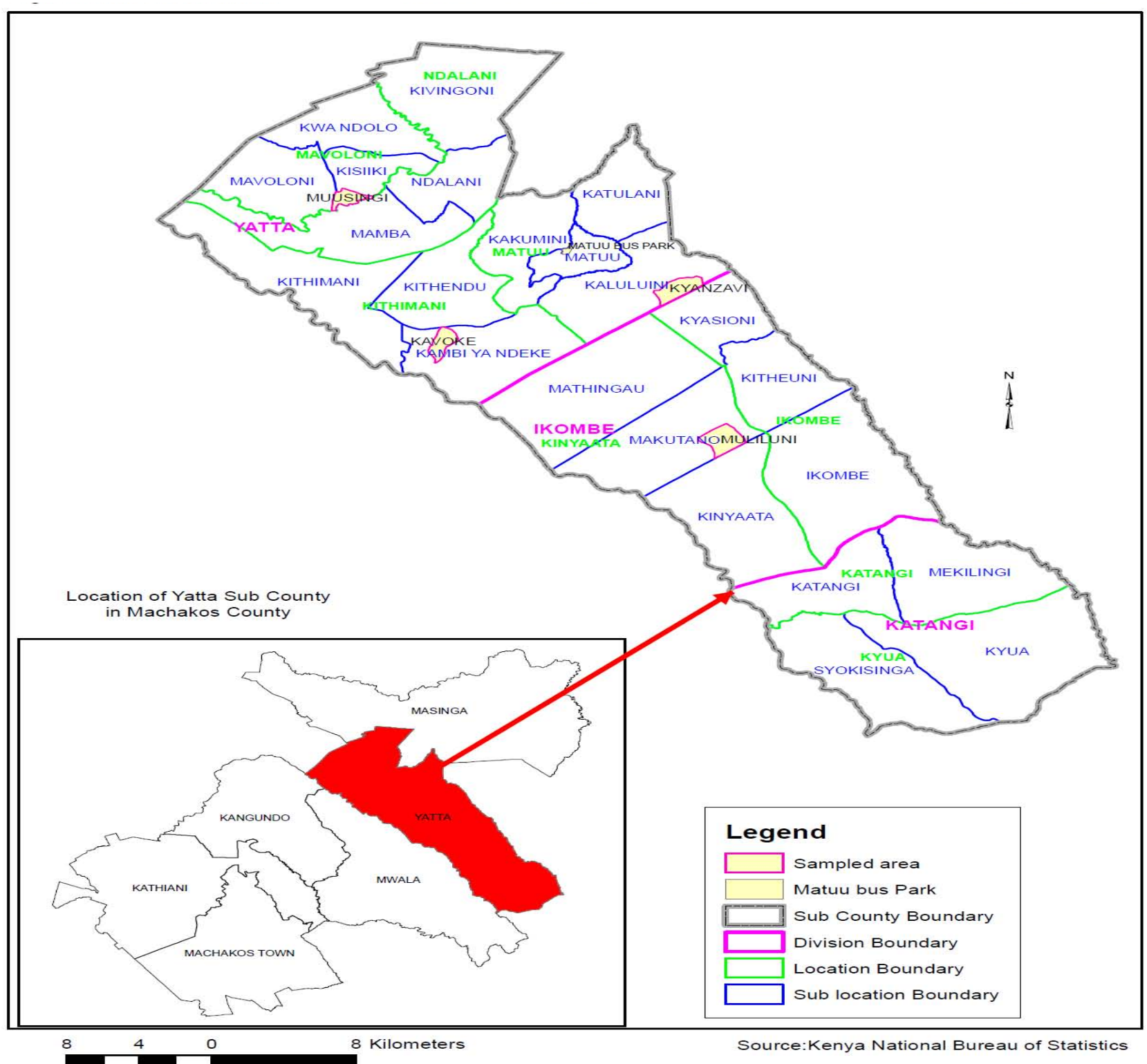

Figure 1: Study Area

\subsection{Data Collection}

Questionnaires were used as instruments for data collection because they are considered economical and easy to formulate and analyze the data. In addition, questionnaires elicit a lot of data and gives greater depth of response.

The questionnaire was divided into two different sections namely Household and Drivers questionnaire. These questionnaire contained questions addressing a particular objective of the study which helped to capture important data which concerns the study. For households, data was captured indicating the Conditions of roads, Pattern of population migration, Security, Social economic, healthy status, availability of water and ease of access to administration.

The drivers questionnaire captured the conditions of roads, types of roads favored for use and the amount they spend to maintain their vehicles.
Raw data from the field was edited to correct errors which might have been made by research assistance during data collection e.g. inappropriate answers given by the respondents. Coding was done to translate question responses into specific categories to reduce research data into manageable summaries. Using GIS and remote sensing the images were analyzed. The coded items were analyzed with the aid of a computer using excel package. Descriptive statistics such as frequencies and percentages were used to analyze quantitative data while qualitative data was analyzed thematically. The analyzed data is presented in form of tables, pie-charts and bar-graphs where applicable.

The handheld GPS was also used to pick geographical coordinates showing location of homestead and any other necessary information such as land marks and any other point of interest. The right parameters of the handheld GPS were set to enable the coordinates to overlay with the shape file accurately. 


\section{International Journal of Science and Research (IJSR) \\ ISSN (Online): 2319-7064}

Index Copernicus Value (2013): 6.14 | Impact Factor (2014): 5.611

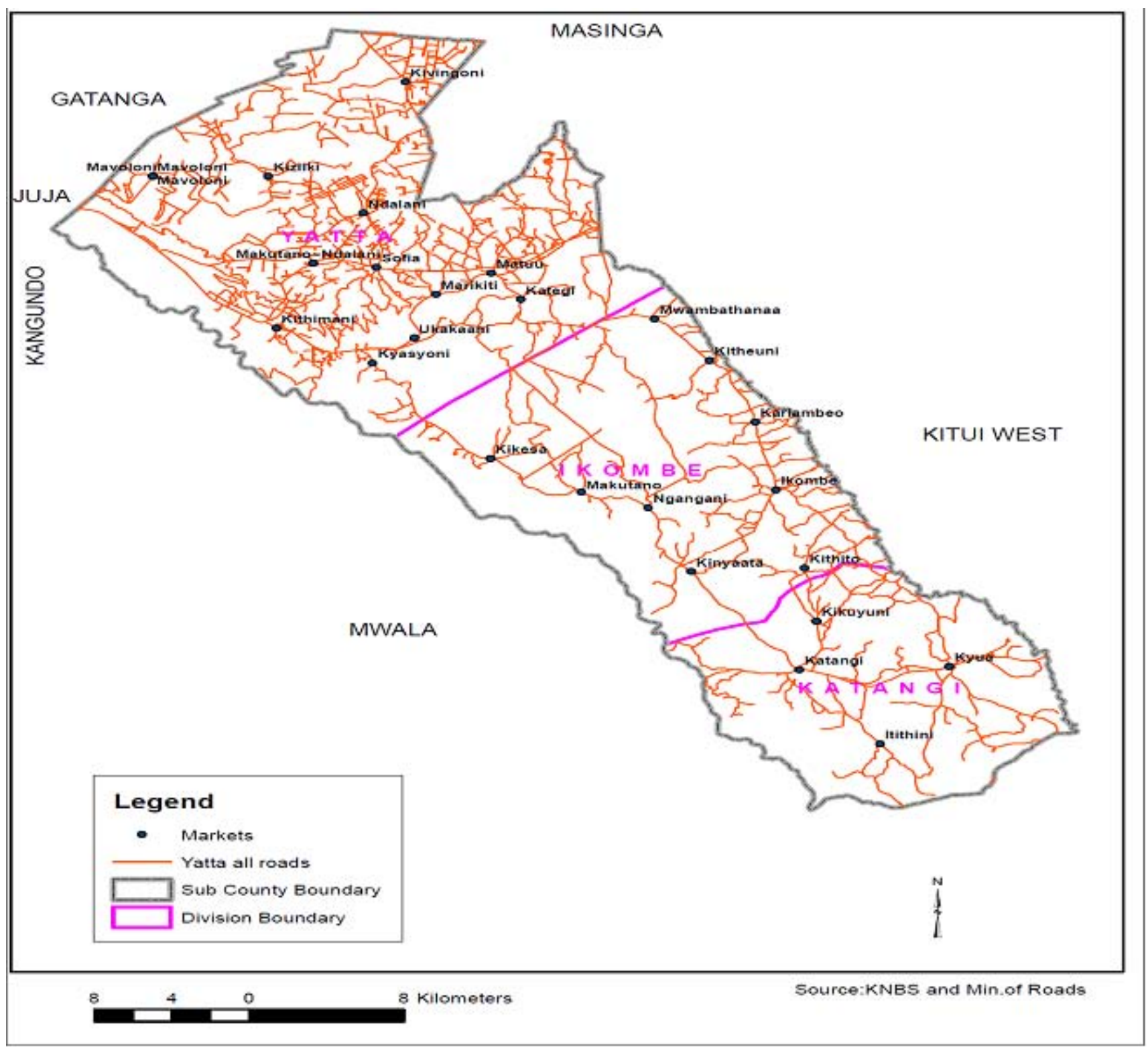

Figure 2: Road Network in Yatta Sub County before classification

\subsection{Target Population}

A population or universe for a study is any group of individuals or institutions which have one or more characteristics in common that are of interest to the researcher (Cooper 1996). This study target farmers (Head of Household) and business owners (Drivers of Public Vehicles) in the Sub County which is a subset of a statistical population.

\subsection{Sampling Technique and Sample Size}

Simple random sampling technique was used to sample respondents for the study. This sampling technique was deemed appropriate as it gives the targeted respondents equal chances to be selected for the study. The members of the subset had equal probability of being chosen. Yatta Sub County has a total of 424 villages and four villages from the total villages were sampled. The sub County had a sample size of 40 respondents from four villages and 10 respondents from Matuu Urban who are drivers of transport sector making a total of 50 sampled respondents. After sampling various villages in the sub County household listing was carried out and the sample of at least ten household per village. Sample Size $424 / 4=106$, so the Interval was 106.

Table 2: Selected Villages after sampling

\begin{tabular}{|c|c|c|c|c|c|c|c|c|c|}
\hline DIV & LOC & SL & EA & AREA_SQKM & Male & Female & Population & Households & Village No. \\
NAME & NAME & NAME & NAME & AR__ & & & & \\
\hline YATTA & Kithimani & Kambi Ya Ndeke & Kavote & 1.88056 & 137 & 162 & 299 & 61 & 04 \\
\hline YATTA & Matuu & Kaluluini & Ngegi/Kya-Nzavi & 6.025864 & 356 & 321 & 677 & 134 & 110 \\
\hline YATTA & Mavoloni & Kisiiki & Muusini & 1.454005 & 199 & 260 & 459 & 88 & 216 \\
\hline IKOMBE & Ikombe & Makutano & Muliluni & 2.43041 & 147 & 130 & 277 & 45 & 322 \\
\hline
\end{tabular}




\section{International Journal of Science and Research (IJSR) \\ ISSN (Online): 2319-7064}

Index Copernicus Value (2013): 6.14 | Impact Factor (2014): 5.611

However, vehicles transport operators were also interviewed to establish the expenses they meet to maintain their vehicle and the time it takes them from the departure to their destination. This involve vehicle from various routes at Matuu market which is the biggest town in this sub county and located at center of the region.

Descriptive statistics such as frequencies ad percentages were used to analyze the quantitative data collected through questionnaires. Qualitative data collected through open ended questions were analyzed thematically.

\subsection{Image Processing}

Image processing involved preprocessing: layer staking, radiometric correction, pan-sharpening, atmospheric correction and sub setting and post processing: Image classification, creating training sites, generating statistical tables, accurate assessment and ground survey using GPS for ground truthing. Preprocessing of data is essential for successful analysis because the images are compared on a pixel basis.

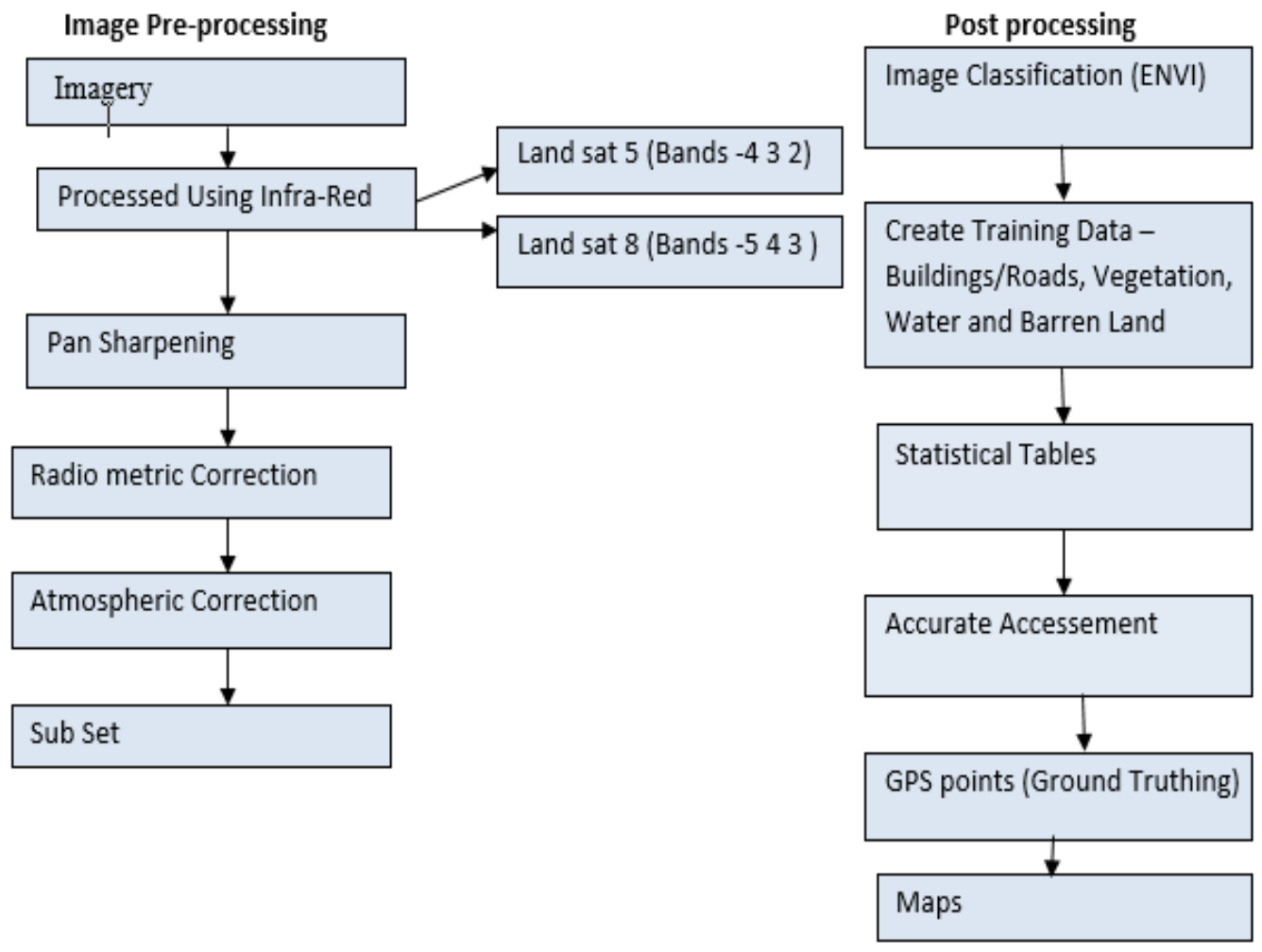

Figure 3: Diagram showing steps of image processing

\section{Result, Conclusions and Recommendations}

This section presents the findings of the study, conclusions and the recommendations.

\subsection{Roads Classification}

Figure 4 and table 3 shows all the road classifications in the Sub County. The region has twenty different types of road Classification. It has four major tarmac roads which go to different destination. The tarmac roads lead to Machakos Kitui, Thika - Kitui, Kithimani -Makutano and Sofiandalani. 


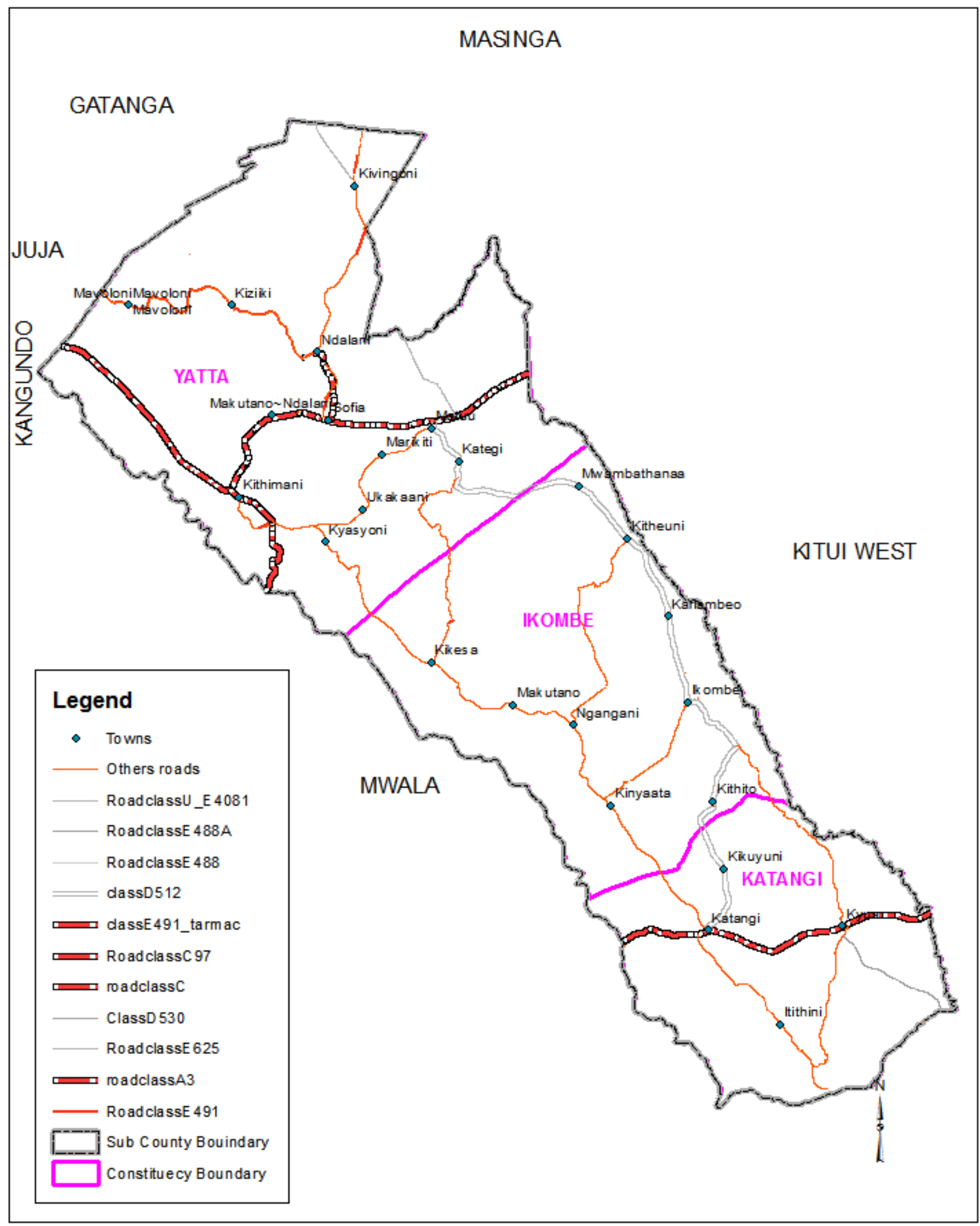

\section{$\begin{array}{llll}7 & 3.5 & 0 & 7 \text { Kilometers }\end{array}$}

Source:KNBS and Min of Roads

Figure 4: Roads Classification

Volume 5 Issue 2, February 2016

www.ijsr.net 


\section{International Journal of Science and Research (IJSR)}

ISSN (Online): 2319-7064

Index Copernicus Value (2013): 6.14 | Impact Factor (2014): 5.611

Table 3: Classification of roads in Yatta Sub County

\begin{tabular}{|c|c|c|c|c|c|}
\hline RID & Surface type & Surface condition & Drainage & Road usage & Length \\
\hline Tarmac Roads & & & & & \\
\hline Class A & Tarmac & Good & & & 0.197861145 \\
\hline C97 & Tarmac & Good & & & 0.765500000 \\
\hline C100 & Tarmac & Fair & & & 0.678729737 \\
\hline E491 & Tarmac & Good & & & 0.199229523 \\
\hline Motorable Murrum Roads & & & & & \\
\hline C100 & Gravel & Fair & None & & 0.410606520 \\
\hline D512 & Earth & Fair & & Used & 0.167701913 \\
\hline Other Roads & & & & & \\
\hline E491 & Surface Dressing & Good & & & 0.076964761 \\
\hline E488A & Earth & Very poor & & & 0.752618112 \\
\hline E488 & Earth & Very Poor & & & 0.697428684 \\
\hline U-E4081 & Earth & Poor & None & Busy & 0.001851197 \\
\hline E716 & Earth & Very Poor & & & 1.066706152 \\
\hline D530 & Earth & Good & & & 2.119034739 \\
\hline E625A & Earth & Poor & & & 0.118566202 \\
\hline E625 & Earth & Poor & & & 0.172791373 \\
\hline U-G210065 & Earth & Very Poor & & & 1.145967562 \\
\hline U-G210072 & Earth & Poor & None & Used & 0.237655696 \\
\hline U-G210066 & Earth & Poor & None & & 0.273876971 \\
\hline U-G210077 & Earth & Poor & None & Used & 0.271886068 \\
\hline U-G210078 & Earth & Poor & None & & 0.425356142 \\
\hline U-G44439-45236 & Earth & Poor & None & & 0.469395208 \\
\hline
\end{tabular}

\subsection{Results}

The table 4 shows there was more settlement in Kavoke village between 2002 and 2015 after the construction of Thika-Kitui Tarmac Road.

Table 5 shows settlement kyanzavi is low since the village has poor road condition.

Table 6 there was an increase in settlement in Muusini village after the construction of Sofia-Ndalani tarmac road.

The table 7 the settlement was more between 1920 and 1940 in Muliluni village.

Table 8 shows the reasons for people to settle in this sub county was for farming and for pasture.

Table 14 indicates $45 \%$ of the respondents cover more than 2 kilometers to reach the schools. This clearly shows the areas need more schools closer to the people.

On economic impact, table 15 shows that $65 \%$ of respondents show that the cost of living is very high due to poor condition of roads as all the other infrastructure relies on road transport. This shows how poor roads have contributed to negative impact on economy of its people. The cost of leaving is high which makes it difficult for the people to meet the basic needs they require.

Table 9 indicates $50 \%$ gets water from the River while table 10 indicate that $30 \%$ walk more than one kilometer to rich the source of water.

Table 11 shows that $60 \%$ of respondents walk more than three kilometers to reach health facilities.
The Table 12 indicates $40 \%$ spend more than ksh.200 to reach the sub county office at Kithimani.

On Security, Table 13 shows we have petty theft which stand at $82.5 \%$ due to the poor condition of the roads cannot enable the patrol of police effectively.

The price of items /commodities is high simply because it is very expensive to transport goods due to poor conditions of roads.

Table 16 indicate that $80 \%$ of public vehicles prefer operating on tarmac roads while table 17 shows vehicle operating on murram roads spend more on maintenance.

Table 18: indicates the data which was collected from responded at the sampled villages before it was analyzed.

Table 4: Year Settled-Kavoke village

\begin{tabular}{|l|r|r|}
\hline Year & Frequency & Percentage \\
\hline $1920-1940$ & 1 & 10 \\
\hline $1941-1979$ & 2 & 20 \\
\hline $1980-2001$ & 3 & 30 \\
\hline $2002-2015$ & 4 & 40 \\
\hline Total & 10 & 100 \\
\hline
\end{tabular}

Table 5: Year Settled-Kyanzavi Village

\begin{tabular}{|l|r|r|}
\hline Year & Frequency & Percentage \\
\hline $1920-1940$ & 3 & 30 \\
\hline $1941-1979$ & 7 & 70 \\
\hline $1980-2001$ & 0 & 0 \\
\hline $2002-2015$ & 0 & 0 \\
\hline Total & $\mathbf{1 0}$ & $\mathbf{1 0 0}$ \\
\hline
\end{tabular}




\section{International Journal of Science and Research (IJSR) \\ ISSN (Online): 2319-7064}

Index Copernicus Value (2013): 6.14 | Impact Factor (2014): 5.611

Table 6: Year Settled-Muusini Village

\begin{tabular}{|l|r|r|}
\hline Year & Frequency & Percentage \\
\hline $1920-1940$ & & \\
\hline $1941-1979$ & 7 & 70 \\
\hline $1980-2001$ & 3 & 30 \\
\hline $2002-2015$ & 0 & 0 \\
\hline Total & $\mathbf{1 0}$ & $\mathbf{1 0 0}$ \\
\hline
\end{tabular}

Table 7: Year Settled-Muliluni Village

\begin{tabular}{|l|r|r|}
\hline Year & Frequency & Percentage \\
\hline $1920-1940$ & 6 & 60 \\
\hline $1941-1979$ & 4 & 40 \\
\hline $1983-2001$ & 0 & 0 \\
\hline $2002-2015$ & 0 & 0 \\
\hline Total & 10 & $\mathbf{1 0 0}$ \\
\hline
\end{tabular}

Table 8: Reasons for Settlement

\begin{tabular}{|l|r|r|}
\hline Response & Frequency & Percentage \\
\hline Farming & 26 & 65 \\
\hline Business & 1 & 2,5 \\
\hline Pasture & 12 & 30 \\
\hline Security & 0 & 0 \\
\hline Road network & 1 & 2,5 \\
\hline Total & 40 & $\mathbf{1 0 0}$ \\
\hline
\end{tabular}

Table 9: Source of Water

\begin{tabular}{|l|r|r|}
\hline Response & Frequency & Percentage \\
\hline River & 20 & 50 \\
\hline Bore hole & 0 & 0 \\
\hline Dam & 15 & 37.5 \\
\hline Piped Water & 2 & 5 \\
\hline well & 3 & 7.5 \\
\hline Total & $\mathbf{4 0}$ & $\mathbf{1 0 0}$ \\
\hline
\end{tabular}

Table 10: Distance to the Source of Water

\begin{tabular}{|l|r|r|}
\hline Kilometers & Frequency & Percentage \\
\hline $0-0.1$ & 6 & 15 \\
\hline $0.11-0.5$ & 11 & 27.5 \\
\hline $0.51-1$ & 11 & 27.5 \\
\hline Above 1 & 12 & 30 \\
\hline Total & $\mathbf{4 0}$ & $\mathbf{1 0 0}$ \\
\hline
\end{tabular}

Table 11: Health facility

\begin{tabular}{|l|r|r|}
\hline Kilometers & Frequency & Percentage \\
\hline $0-1$ & 0 & 0 \\
\hline $1.1-2$ & 2 & 5 \\
\hline $2.1-3$ & 14 & 35 \\
\hline Above 3 & 24 & 60 \\
\hline Total & $\mathbf{4 0}$ & $\mathbf{1 0 0}$ \\
\hline
\end{tabular}

Table 12: Transport cost from home to the Administration Office (Sub County Office)

\begin{tabular}{|l|r|r|}
\hline K/Shillings & Frequency & Percentage \\
\hline $0-50$ & 2 & 5 \\
\hline $51-100$ & 8 & 20 \\
\hline $101-200$ & 14 & 35 \\
\hline Above 200 & 16 & 40 \\
\hline Total & $\mathbf{4 0}$ & $\mathbf{1 0 0}$ \\
\hline
\end{tabular}

Table 13: Insecurity

\begin{tabular}{|l|r|r|}
\hline & Frequency & Percentage \\
\hline Thurgery & 7 & 17.5 \\
\hline Pet theft & 33 & 82.5 \\
\hline Total & $\mathbf{4 0}$ & $\mathbf{1 0 0}$ \\
\hline
\end{tabular}

Table 14: Distance to school

\begin{tabular}{|l|r|r|}
\hline Kilometers & Frequency & Percentage \\
\hline $0-1$ & 14 & 35 \\
\hline $1.1-2$ & 8 & 20 \\
\hline Above 2 & $\mathbf{1 8}$ & $\mathbf{4 5}$ \\
\hline Total & $\mathbf{4 0}$ & $\mathbf{1 0 0}$ \\
\hline
\end{tabular}

Table 15: Economic Impact

\begin{tabular}{|l|r|r|}
\hline Age & Frequency & Percentage \\
\hline Low & 2 & 5 \\
\hline Moderate & 10 & 25 \\
\hline High & 26 & $\mathbf{6 5}$ \\
\hline Not Sure & 2 & 2 \\
\hline Total & $\mathbf{4 0}$ & $\mathbf{1 0 0}$ \\
\hline
\end{tabular}

Table 16: Commonly used Roads

\begin{tabular}{|l|r|r|}
\hline & Frequency & Percentage \\
\hline Tarmac & 8 & 80 \\
\hline Murram & 2 & 20 \\
\hline Total & $\mathbf{1 0}$ & $\mathbf{1 0 0}$ \\
\hline
\end{tabular}

Table 17: Vehicle maintenance

\begin{tabular}{|l|r|r|r|}
\hline Road Type & K/shillings & Frequency & Percentage \\
\hline Tarmac & $3000-4000$ & 3 & 30 \\
\hline Tarmac & Above 6000 & $\mathbf{5}$ & $\mathbf{5 0}$ \\
\hline Murram & $9000=1000$ & 2 & 20 \\
\hline Total & & $\mathbf{1 0}$ & $\mathbf{1 0 0}$ \\
\hline
\end{tabular}




\section{International Journal of Science and Research (IJSR) \\ ISSN (Online): 2319-7064}

Index Copernicus Value (2013): 6.14 | Impact Factor (2014): 5.611

Table 18: Data By respondent

\begin{tabular}{|c|c|c|c|c|c|c|c|c|c|c|c|c|}
\hline \begin{tabular}{|c|} 
EA- \\
NAME
\end{tabular} & HH NAME & $\mathrm{HH}$ & $\begin{array}{l}\mathrm{HH} \\
\text { Size }\end{array}$ & \begin{tabular}{|l|} 
Year home \\
established
\end{tabular} & Reasons to settle & \begin{tabular}{|c|} 
Distance \\
to water \\
$(\mathrm{Km})$
\end{tabular} & $\begin{array}{c}\text { Road } \\
\text { condition }\end{array}$ & $\begin{array}{c}\text { Adequacy } \\
\text { of Road }\end{array}$ & Bus fare & $\begin{array}{l}\text { Health } \\
\text { facility } \\
(\mathrm{Kms})\end{array}$ & $\begin{array}{c}\text { Source } \\
\text { of } \\
\text { water }\end{array}$ & $\begin{array}{l}\text { Admn. } \\
\text { Off } \\
\text { (Min) }\end{array}$ \\
\hline \multirow{9}{*}{$\begin{array}{c}\text { KYAN } \\
\text { ZAVI }\end{array}$} & MBITHI KIOKO & 10 & 6 & 1945 & Farming/pasture & 2 & Poor & No & High & 3 & River & 60 \\
\hline & $\begin{array}{l}\text { MUTHUKU } \\
\text { NDAMBUKI }\end{array}$ & 16 & 5 & 1940 & Farming/pasture & 1 & Poor & No & High & 2 & River & 60 \\
\hline & NDOLO KILONZO & 22 & 6 & 1940 & Farming/pasture & 2 & Poor & No & High & 2 & River & 60 \\
\hline & NZAMU MUTUA & 28 & 6 & 1960 & Farming/pasture & 2 & Poor & No & High & 2 & River & 60 \\
\hline & KIILU KATUMO & 34 & 7 & 1970 & Farming/pasture & 2 & Poor & No & High & 3 & River & 60 \\
\hline & KYALO KISILU & 40 & 5 & 1970 & Farming/pasture & 2 & Poor & No & High & 2 & River & 45 \\
\hline & MULEI KAVOI & 46 & 12 & 1960 & Farming/pasture & 2.5 & Poor & No & High & 3 & River & 60 \\
\hline & $\begin{array}{l}\text { KITHENGE } \\
\text { KASENGA }\end{array}$ & 52 & 5 & 1940 & Farming/pasture & 2 & Poor & No & High & 4 & River & 60 \\
\hline & MUTISYA KASYOKI & 58 & 7 & 1960 & Farming/pasture & 2 & Poor & No & High & 5 & River & 30 \\
\hline \multirow{10}{*}{$\begin{array}{c}\text { KAVO } \\
\text { KE }\end{array}$} & PETER MUTHAMA & 2 & 5 & 1960 & Farming/pasture & 0.25 & & No & Moderate & 4 & River & 60 \\
\hline & GEORGE & 7 & 7 & 1980 & Farming/pasture & 1 & Poor & No & Moderate & 3 & River & 30 \\
\hline & JOHN NGUMBI & 12 & 6 & 1995 & Farming/pasture & 1 & Poor & No & Moderate & 3 & River & 20 \\
\hline & KIMEU KILONZO & 17 & 9 & 2002 & Farming/pasture & 1 & Poor & No & Moderate & 4 & River & 30 \\
\hline & WAYU MBITHI & 22 & 2 & 1952 & Farming/pasture & 0.1 & Poor & No & Moderate & 3 & River & 30 \\
\hline & MUTHINI MUINDE & 27 & 9 & 1940 & Farming/pasture & 1 & Poor & No & Moderate & 2 & River & 30 \\
\hline & PIUS MWETU & 32 & 4 & 1990 & Farming/pasture & 1 & Poor & No & Moderate & 4 & River & 30 \\
\hline & \begin{tabular}{|l|} 
JOSEPHINE KINGOO \\
\end{tabular} & 37 & 4 & 2007 & hg/pasture & 0.15 & Poor & No & Moderate & 3 & River & 20 \\
\hline & TITUS KIOKO & 42 & 4 & 2003 & Farming/pasture & 0.2 & Poor & No & Moderate & 4 & River & 30 \\
\hline & JOSEPH MUOKI & 47 & 5 & 2010 & Farming/pasture & 0.2 & Poor & No & Moderate & 4 & River & 30 \\
\hline \multirow{10}{*}{$\begin{array}{c}\text { MUUSI } \\
\text { NI }\end{array}$} & MUTISO LINDA & 3 & 6 & 1972 & Farming/pasture & 0.1 & Poor & No & Moderate & 4 & River & 30 \\
\hline & $\begin{array}{l}\text { BENEDETA } \\
\text { MATHEKA }\end{array}$ & 10 & 4 & 1982 & Farming/pasture & 0.5 & Poor & No & High & 4 & River & 60 \\
\hline & MICHAEL KISILU & 17 & 3 & 1968 & Farming/pasture & 0.8 & Poor & No & High & 2 & River & 30 \\
\hline & JULIUS ZAKAYO & 24 & 9 & 1976 & $\mathrm{~g} /$ pasture & 0.1 & Poor & No & High & 3 & River & 45 \\
\hline & JOSEPH WAMBUA & 31 & 5 & 1972 & Farming/pasture & 0.4 & Poor & No & High & 3 & River & 60 \\
\hline & RICHARD FORO & 38 & 9 & 1970 & Farming/pasture & 0.4 & Poor & No & High & 3 & River & 30 \\
\hline & MUSAU KITONYI & 45 & 4 & 1978 & Farming/pasture & 0.6 & Poor & No & High & 3 & River & 30 \\
\hline & BENEDICT KILONZO & 52 & 5 & 1963 & Farming/pasture & 0.1 & Poor & No & High & 3 & River & 60 \\
\hline & JOHN MAKUMBI & 59 & 8 & 1982 & Farming/pasture & 0.1 & Poor & No & High & 4 & River & 45 \\
\hline & MULEI MATIVO & 66 & 3 & 1980 & Farming/pasture & 0.3 & Poor & No & High & 3 & River & 60 \\
\hline \multirow{10}{*}{$\begin{array}{c}\text { MULIL } \\
\text { UNI }\end{array}$} & MUSAU NDUTU & 2 & 7 & 1950 & Farming/pasture & 0.5 & Poor & No & High & 3 & River & 120 \\
\hline & MUTISO KING ${ }^{\circ e} \mathrm{OO}$ & 6 & 9 & 1960 & Farming/pasture & 1 & Poor & No & High & 3 & River & 60 \\
\hline & KAUNDA KING ${ }^{e e} \mathrm{OO}$ & 10 & 9 & 1940 & Farming/pasture & 0.3 & Poor & No & High & 4 & River & 60 \\
\hline & WAMBUA MUSEMBI & 14 & 11 & 1939 & Farming/pasture & 2 & Poor & No & High & 5 & River & 120 \\
\hline & $\begin{array}{l}\text { MUSYOKI } \\
\text { MUALUKO }\end{array}$ & 18 & 7 & 1939 & Farming/pasture & 2.5 & Poor & No & High & 4 & River & 60 \\
\hline & MUASA MBULI & 22 & 7 & 1929 & Farming/pasture & 1 & Poor & No & High & 3 & River & 30 \\
\hline & KAUNI MWALUKO & 26 & 14 & 1920 & Farming/pasture & 2 & Poor & No & High & 4 & River & 30 \\
\hline & \begin{tabular}{|l|} 
NTHUKU MUSEMBI \\
\end{tabular} & 30 & 7 & 1930 & Farming/pasture & 1 & Poor & No & High & 4 & River & 45 \\
\hline & \begin{tabular}{|l|} 
MUTUNGA KIVUVA \\
\end{tabular} & 34 & 8 & 1979 & $\mathrm{~g} /$ pasture & 0.2 & Poor & No & High & 5 & River & 60 \\
\hline & KAMAU MUTUA & 38 & 8 & 1969 & Farming/pasture & 0.1 & Poor & No & High & 5 & River & 5 \\
\hline
\end{tabular}

\subsection{Conclusions}

From the findings of the study, it can be concluded that roads play an important role in infrastructure and services in any rural set up to be developed. This was also established in its importance to the Yatta Sub County as the level of capital accumulation embodied in infrastructure development, hence it is a crucial factor determining the pace and diversity of economic development in any society. Although the direct link exists between productive investments and growth, social and economic infrastructure (such as roads, electricity, water and sanitation, and communications) facilitates and integrates economic activities.

The study also concludes that roads which cover the Sub County are not sufficient to serve the people of Yatta Sub County effectively. Most of the in-roads in this sub County are in very poor conditions whereby people need to use motor cycle to reach their destinations. Where roads are in good conditions, growth of towns search as Matuu, Kithimani and Katangi has greatly grown.

It was finally concluded that the cost of living is very high in the Sub-County. This resulted from poor conditions of roads making road users spent a lot of time while travelling from one point to another. Most of areas are served by public vehicles only once by one matatu which usually goes to Matuu in the morning and gets back in the evening.

\subsection{Recommendations}

In this Sub County many roads needs to be upgraded in order to improve the livelihoods of the people in Yatta. Currently, the area has four tarmacked roads which have generally improved the transport sector within the areas where it serves. However due to expansiveness of the area,

\section{Volume 5 Issue 2, February 2016}




\section{International Journal of Science and Research (IJSR) \\ ISSN (Online): 2319-7064}

Index Copernicus Value (2013): 6.14 | Impact Factor (2014): 5.611

more roads need to be improved in order to improve other types of infrastructure. The road from Katangi to Matuu via Ikombe should be Tarmac in order to enable transport of quarry stones from Ikombe which is a major income generating activity to the people around the area.

Other roads which should be improved for better murram roads are - Katangi-Kikesa-Kithimani, Mavoloni-Kisiiki, Ndalani-Kavingoni, and Kyasioni-Matikiti Matuu Roads. The County Governments should put necessary structures to enabled sustained maintenance of roads infrastructures. Most of the rivers have no bridges and even the ones which have underground bridges which are not safe during rainy season.

The County Government should embrace use of GIS to make decision making and planning. This can be very useful to Engineers to monitor any changes and can store large information and manipulate it. The use of remote sensing will help gather lots of information which is precise and cheap to acquire.

\section{References}

[1] Richardson, T. and Jensen, O.B. (2000). "Discourses of mobility and Polycentric Development: A Contested View of European Spatial Planning ". European Planning Studies.

[2] Hildén, M.; Furman, E. \& Kaljonen, M. (2004). Views on planning and expectations of SEA. the case of transport planning. Environmental Impact Assessment Review, 24, 519-536.

[3] Short, J. \& Kopp, A. (2005). Transport infrastructure. Investment and planning. Policy and research aspects. Transport Policy, 12, 360-367.

[4] Hine, J.P. (1998). Roads, regulation and road user behaviour. Journal of Transport Geography, 6 (2), 143158.

[5] European Commission (1998). The Common Transport Policy. Sustainable Mobility. Perspectives for the Future, Commission Communication to the Council, European Parliament, Economic and Social Committee and Committee of the Regions.

[6] US Department of Transportation (2000). Strategic Plan 2000-2003. Department of Transportation. USA.

[7] Abaza, H., Baranzini, A., (2002). Implementing Sustainable Development. Integrated Assessment and Participatory DecisionMaking Processes. UNEP and Edward Elgar, Cheltenham, UK and Northampton, Ma, USA.

[8] Boulanger, P.M., Brechet, T. (2005). Overview, classification and characterization of scientific tools for sustainable development decision-making. Booklet for Research Programs, European Commission and Belgian Science Policy Workshop, 28-29 November, Brussels.

[9] Romp, W. \& De-Haan, J. (2005). Public capital and economic growth: A critical survey. EIB Papers, 10(1), 40-93.

[10] Owen, W. (1968). Distance and development. The Brooking Institution, Washington D.C.

\section{Author Profile}

Peter M.Muthama received a Bachelor"s degree in Geography from University Of Nairobi 2013 and is currently pursuing his Masteres degree in Geospatial Information system and Remote sensing from Dedan Kimanthi University of Technology .He works with Kenya National Bureau of Statistics at GIS and Cartography Section which deals with preparing maps for Census.

Kenneth Mubea has wide knowledge of Geomatics, GIS and Remote sensing and their applications in numerous fields. He is a Lecturer at Dedan Kimathi University of Technology, Nyeri, Kenya. He holds a Bachelor"s degree in Geomatic Engineering from Jomo Kenyatta university of Agriculture and technology (Kenya), an MSc degree in GIS and Remote Sensing from Jomo Kenyatta university of Agriculture and technology (Kenya) and a $\mathrm{PhD}$ in Remote Sensing \& GIS from University of Bonn (Germany). He has authored many papers and attended various international confe-rences. His interests are urban growth modeling, remote sensing, cellular automata, GIS, Land information systems (LIS), surveying, Geodesy, web mapping among other related disciplines in Geomatics.

Prof. Charles N. Mundia has Considerable research and teaching experience in Geomatic Engineering, GIS and Remote Sensing analyses of over nine years both locally and internationally. Two year post-doctoral research experience at the school of Integrative Environmental Science, University of Tsukuba. , Served as an associate professor of GIS and Remote Sensing for two years at the Centre for Spatial Information Science, University of Tsukuba, Japan.. Served as head of department and a senior lecturer at the department of Geomatic Engineering and Geospatial Information Science of Jomo Kenyatta University. Currently an Associate Professor of Geoinformatics at Dedan Kimathi University of Agriculture and Technology, Institute of Geomatic, GIS and Remote Sensing. Authored two University level books published by Nova Science publishers (USA) and Lambert Publishing Company (Germany) and have published widely in high impact international journals on Remote sensing and GIS analyses. Appears in the "Who is Who" in Science and Engineeringee, eleventh edition (2011-2012) by Marquis who is who publication board of United States. 